\title{
Correction to: Assessing rare diseases prevalence using literature quantification
}

\author{
Jason Shourick $^{1 *} \mathbb{C}$, Maxime Wack ${ }^{1}$ and Anne-Sophie Jannot ${ }^{1,2}$
}

\section{Correction to:}

Orphanet Journal of Rare Diseases (2021) 16:139

https://doi.org/10.1186/s13023-020-01639-7

Following the publication of the original article [1] the authors brought to our attention that their first and last names had unfortunately been interchanged.

The correct authors' names are shown in the author list of this Correction and have already been updated in the original article.

\section{Author details}

'Department of Medical Informatics, Hôpital Européen Georges Pompidou, AP-HP, 20 Rue Leblanc, 75015 Paris, France. ${ }^{2}$ INSERM, Centre de Recherche des Cordeliers, UMRS 1138, Université de Paris, Université Sorbonne Paris Cité, Paris, France.
Published online: 10 May 2021

\author{
Reference \\ 1. Shourick, et al. Assessing rare diseases prevalence using literature \\ quantification. Orphanet J Rare Dis. 2021;16:139. https://doi.org/10.1186/ \\ s13023-020-01639-7.
}

\section{Publisher's Note}

Springer Nature remains neutral with regard to jurisdictional claims in published maps and institutional affiliations.

(c) The Author(s) 2021. This article is licensed under a Creative Commons Attribution 4.0 International License, which permits use, sharing, adaptation, distribution and reproduction in any medium or format, as long as you give appropriate credit to the original author(s) and the source, provide a link to the Creative Commons licence, and indicate if changes were made. The images or other third party material in this article are included in the article's Creative Commons licence, unless indicated otherwise in a credit line to the material. If material is not included in the article's Creative Commons licence and your intended use is not permitted by statutory regulation or exceeds the permitted use, you will need to obtain permission directly from the copyright holder. To view a copy of this licence, visit http://creativecommons.org/licenses/by/4.0/. The Creative Commons Public Domain Dedication waiver (http://creativecommons.org/publicdomain/zero/1.0/) applies to the data made available in this article, unless otherwise stated in a credit line to the data. 